\title{
PEMELIHARAAN LARVA KERAPU BEBEK Cromileptes altivelis DENGAN PADAT TEBAR BERBEDA
}

\author{
Titiek Aslianti*
}

\begin{abstract}
ABSTRAK
Di antara empat jenis larva ikan perairan tropis (kerapu, baronang, kakap dan bandeng), yang paling sulit dipelihara adalah larva kerapu. Kendala utama dalam pemeliharaan larva selain ukuran mulut yang sangat kecil, ukuran pakan yang tidak sesuai juga padat tebar larva dalam tangki pemeliharaan.

Tujuan dilakukan percobaan pemeliharaan larva kerapu bebek, Cromileptes altivelis dengan padat tebar berbeda untuk mengetahui kepadatan larva optimal yang dapat memanfaatkan pakan secara efektif dan tingkat sintasan yang tinggi. Percobaan menggunakan tangki kaca serat berkapasitas $1.000 l$, diisi telur fase embryo kepadatan (A) 25, (B) 50 dan (C) 75 butir/l. Dalam pemeliharaan selama 30 hari larva diberi pakan berupa rotifer (5-30 ind./ml) dan pakan buatan $\left(0,5-1 \mathrm{~g} / \mathrm{m}^{3}\right)$ serta Chlorella (1 juta $\mathrm{sel} / \mathrm{ml}$ ) sebagai penstabil lingkungan (green water). Hasil percobaan menunjukkan sintasan larva tertinggi pada hari ke-5 dicapai pada perlakuan A sebesar $29,40 \%$, diikuti B $(19,46 \%)$ dan terendah C $(10,29 \%)$. Namun sampai dengan hari ke-30 semua perlakuan menunjukkan sintasan yang menurun. Sintasan perlakuan B (50 ind./l) pada hari ke30 sebesar $1,95 \%$ dan secara nyata $(\mathrm{P}<0,05)$ lebih tinggi daripada perlakuan $\mathrm{A}(0,05 \%)$ dan $\mathrm{C}$ $(0,2 \%)$. Panjang total larva antar perlakuan pada pengamatan setiap 5 hari selama 30 hari tidak berbeda $(\mathrm{P}>0,05)$.
\end{abstract}

\section{ABSTRACT: Larval Rearing of the Grouper, Cromileptes altivelis at Different Stocking Densities. By: Titiek Aslianti.}

The most difficult species to rear among of the four tropical marine fish larvae species (grouper Epinephelus sp., rabbitfish Siganus sp., seabass Lates calcarifer and milkfish Chanos chanos) is the grouper. The main problem in larval rearing of the grouper are small mouth size, unconform feed size and stocking densities in the larvae tank.

The purpose of the reasearch was to know the optimum density of the larvae that could consumed feed effectively and can increase the survival rate of the larvae. The experiment using $1,000 l$ capacity transparant fibreglass tanks with the outerwall were painted black. The tanks filled with $500 \mathrm{l}$ of sea water (32-34 ppt) and stocked with embryo phase eggs at density of A (25 pcs. $/ l), \mathrm{B}(50 \mathrm{pcs} . / l)$ and $\mathrm{C}(75 \mathrm{pcs} . / l)$. The experiment was conducted for 30 days and the larvae were fed with rotifer $(5-30 \mathrm{ind} . / \mathrm{ml})$ and artificial feed $\left(0.5-1.0 \mathrm{~g} / \mathrm{m}^{3}\right)$. Chlorella at $1 \mathrm{million} \mathrm{cel} / \mathrm{ml}$ density was provided as green water to feed the rotifer.

The result showed that the highest survival rate on the d-5 (29.40\%) was observed in treatment A, followed by treatment B (19.46\%) and C $(10.29 \%)$. But the survival rate for all treatments were drastically decreased on the d-30. The survival rate of B (50 pcs. $/ l)$ on the d-30 $(1.95 \%)$ is the highest and significantly different $(\mathrm{P}<0.05)$ to $\mathrm{A}(0.05 \%)$ and $\mathrm{C}(0.2 \%)$. There were no significant different in total length of the larvae for all treatments observed at 5 day interval during 30 days rearing period $(\mathrm{P}>0.05)$.

\section{KEYWORDS: Larvae of Grouper, stocking density, survival rate.}

\section{PENDAHULUAN}

Budidaya ikan kerapu dengan sistem karamba jaring apung sudah banyak dilakukan dibeberapa wilayah Indonesia dengan tujuan utama ekspor. Usaha ini tampaknya menguntungkan sehingga dari tahun ke tahun jumlahnya cenderung meningkat.

Pada ukuran konsumsi (marketable size) jenis ikan kerapu sangat digemari di pasaran dalam dan luar negeri terutama dalam keadaan segar

") Peneliti pada Loka Penelitian Perikanan Pantai Gondol, Bali. 
dan hidup yang merupakan pasokan bagi restoran hasil laut (sea food). Pemasaran ikan hidup dengan harga yang jauh lebih baik mendorong para pemasok untuk memperoleh ikanikan tersebut dari hasil usaha budidaya, karena penyediaan ikan dalam keadaan hidup dengan mutu yang baik lebih terjamin.

Dari beberapa jenis kerapu di Indonesia, kerapu bebek adalah satu di antara jenis ikan keluarga Seranidae yang mempunyai nilai ekonomis bahkan termahal di Asia Tenggara (Mishina and Gonzares, 1994). Tekstur dagingnya yang lembut dan kokoh/kenyal menyebabkan ikan ini banyak digemari masyarakat Hongkong, Singapura, Jepang, Taiwan dan Thailand. Selain diekspor untuk konsumsi, kerapu bebek pada ukuran tertentu banyak diperdagangkan sebagai ikan hias (Kohno et al., 1990a; Ahmad dan Sunyoto, 1990; Ahmad et al., 1991; Chintahikul, 1986).

Dalam usaha budidaya, akhir-akhir ini kerapu bebek semakin sulit didapatkan dibanding jenis kerapu lain. Melihat prospeknya yang cerah sejalan dengan pangsa pasar yang berpeluang cukup besar, usaha budidaya belumlah cukup sebagai pemasok yang kontinu, mengingat pasok benih masih mengandalkan dari alam sehingga dikhawatirkan akan terjadi penangkapan secara intensif. Untuk mengantisipasi kesenjangan antara pangsa pasar dan pasok benih perlu dilakukan rintisan perbenihan yang bertujuan untuk mencukupi permintaan konsumen secara kontinu dan pemikiran ke arah pelestarian populasinya di alam akibat penangkapan intensif.

Upaya perbenihan ikan kerapu macan (Epinephelus fuscoguttatus), kerapu lumpur ( $E$. suillus) dan kerapu sunu (Plectropomus maculatus) sudah berhasil dilakukan namun pemeliharaan larva dalam skala besar (massal) masih banyak menemui kendala di antaranya angka kematian larva pada umur 1.7 hari dan setelah 20 hari masih tinggi. Keadaan tersebut sering disebabkan oleh faktor lingkungan, kualitas telur, jenis, jumlah dan ukuran pakan larva, waktu dan frekuensi makanan, juga padat penebaran larva (Mayunar et al., 1991). Penelitian Waspada et al. (1991) menggunakan larva kerapu macan $(E$. fuscoguttatus) dengan padat tebar 70 ind./l menghasilkan sintasan $10,83 \%$ pada d-14, sedang Purba dan Redjeki (1992) melaporkan bahwa larva kerapu sunu ( $P$. maculatus) dapat di- pelihara dengan padat tebar 5-20 ind./l dalam tangki berkapasitas 30 liter selama 5 hari pemeliharaan (d-5) menghasilkan sintasan 15 . $16,5 \%$. Rendahnya tingkat sintasan larva dengan waktu pemeliharaan yang relatif singkat belum mencerminkan keberhasilan perbenihan yang optimal. Aplikasi kapasitas wadah, padat penebaran, jenis pakan awal dan waktu pemeliharaan larva hingga mencapai ukuran siap tebar untuk kegiatan budidaya (ikan konsumsi dan ikan hias) perlu diketahui dalam menunjang sintasan larva yang optimal. Berdasarkan pertimbangan tersebut dilakukan penelitian padat tebar larva kerapu bebek dalam wadah ber. kapasitas $1.000 l$, dengan tujuan mengetahui kepadatan larva optimal yang dapat memanfaatkan pakan secara efektif selama pemeliharaan 30 hari sehingga tingkat kematian larva dapat ditekan.

\section{BAHAN DAN METODE}

Wadah percobaan berupa bak silinder kaca serat berkapasitas $1.000 l$ yang dinding luarnya dicat hitam. Masing-masing wadah diisi air laut $500 l(32-34 \mathrm{ppt})$ yang disaring menggunakan kantong filter. Telur diperoleh dari hasil pemijahan alami induk-induk kerapu bebek yang dipelihara pada bak terkontrol $\left(30 \mathrm{~m}^{3}\right)$, setelah diseleksi diinkubasikan sampai mencapai fase embrio (15 jam setelah pembuahan). Telur-telur tersebut ditetaskan dalam masing-masing wadah dengan kepadatan (A) 25, (B) 50 dan (C) 75 butir/l yang merupakan perlakuan. Mengingat setiap pemijahan, jumlah stok telur yang tersedia sangat terbatas maka masing-masing perlakuan hanya diulang dua kali. Selanjutnya telur dalam wadah diaerasi dan diharapkan menetas sem. purna. Pada saat telur menetas (d-0) jumlah larva pada masing-masing bak dihitung sehingga diketahui daya tetas telur yang ditebar. Pakan larva berupa rotifer diberikan pada saat larva mulai membuka mulut, yaitu pada d-2 sebanyak 2-5 ind./ml dan Chlorella dengan kepadatan 0,5-1 juta sel/ml. Kepadatan rotifer meningkat $10-15$ ind. $/ \mathrm{ml}$ dan $20-30 \mathrm{ind} . / \mathrm{ml}$ masing-masing pada $\mathrm{d}-5$ sampai d-8 dan d-10 sampai d-15. Selanjutnya setelah d-15 pada pagi hari larva diberi pakan tambahan (pakan komersial powder) sebanyak $0,1-0,2 \mathrm{~g} / \mathrm{m}^{3} /$ hari sampai larva berumur 20 hari. Sore hari tetap diberi rotifer dengan kepadatan $30-40$ ind. $/ \mathrm{ml}$. Pemberian pakan buatan meningkat $0,5-1 \mathrm{~g} / \mathrm{m}^{3} /$ hari hingga larva berumur 30 
hari. Sisa pakan dan sisa metabolisme (ekskresi) pada dasar bak dibersihkan menggunakan alat sifon dilakukan setiap hari mulai hari ke-10 bersamaan dengan pergantian air sebanyak \pm 10 $30 \%$. Panjang total dan tingkat sintasan larva diamati setiap 5 hari mulai d-5 sampai d-30. Pengukuran panjang total menggunakan alat mikrometer perbesaran 10-40 X, dengan cara mengambil sampel sebanyak 5-10 ekor. Sintasan larva diketahui melalui 5 kali pengambilan sampel dari masing-masing bak pada malam hari. Data penunjang berupa kualitas air seperti suhu, $\mathrm{pH}$, salinitas, DO, kandungan nitrit dan amonia dipantau setiap 3 hari selama 30 hari.

\section{HASIL DAN PEMBAHASAN}

Rata-rata jumlah telur yang menetas (d-0) pada masing-masing bak penelitian berturutturut A, B dan C sebesar $88,6 \%, 90 \%$ dan $87 \%$ yang menunjukkan bahwa kualitas telur pada saat ditebar dalam bak pemeliharaan berada dalam kondisi baik. Di antara perlakuan A, B dan $\mathrm{C}$ pada d-5 sampai d-30 menunjukkan tingkat sintasan yang tidak berbeda nyata $(\mathrm{P}>0,05)$ dan cenderung menurun di akhir penelitian (Figure 1) namun perlakuan $B$ nampak memberikan hasil lebih tinggi $(1,95 \%)$ dari pada perlakuan $\mathrm{A}$ $(0,05 \%)$ dan $\mathrm{C}(0,20 \%)$.
Menurunnya tingkat sintasan larva secara tajam pada stadia awal (d1-d5) dipengaruhi beberapa faktor yang diduga berkaitan erat dengan ketersediaan pakan awal baik dalam jumlah, jenis serta ukuran yang sesuai dengan perkembangan umur larva. Melalui pengamatan mikroskop diketahui bahwa cadangan makanan berupa kuning telur dan gelembung minyak telah habis diserap pada hari ke dua dan kondisi larva nampak masih sangat lemah, bergerak mengikuti arus serta peka terhadap perubahan lingkungan sehingga daya pemangsaan larva terhadap pakan masih sangat rendah. Pada kondisi demikian untuk mempertahankan sintasannya larva memerlukan pakan dalam jumlah optimal yang selalu berada di sekitar tubuhnya sehingga larva tidak memerlukan energi yang besar dalam memperoleh makanannya. Namun karena bukaan mulut larva saat pertama kali makan (54-59 jam setelah penetasan) sangat kecil ( $\pm 105 \mu \mathrm{m})$ dibanding ukuran rotifer (150-180 $\mu \mathrm{m})$ sehingga pakan yang tersedia tidak dimanfaatkan dan mengakibatkan kematian, terbukti dari kosongnya rongga pencernaan larva yang diamati melalui mikroskop. Keadaan ini sesuai dengan pendapat Kohno et al., (1994) yang menyatakan bahwa ukuran larva kerapu umumnya sangat kecil baik ukuran tubuh maupun mulut dan pemangsaan terhadap pakan awal sangat rendah.

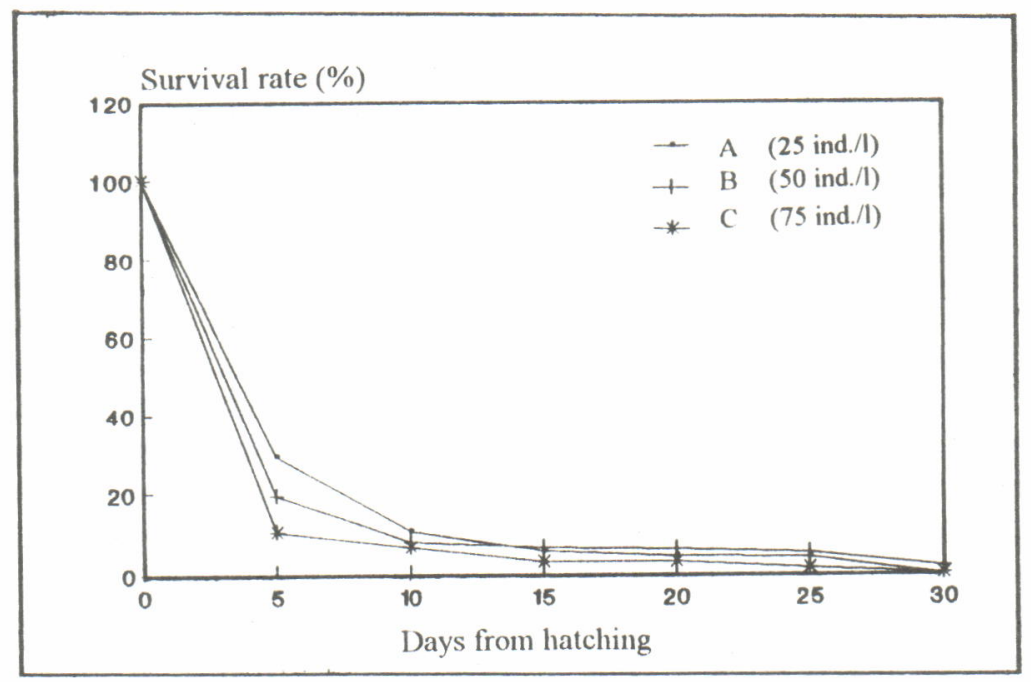

Figure 1. Average survival rate (\%) of grouper, Cromileptes altivelis larvae on $d-5$ to $d-30$ reared at different stocking density. 
Dibanding ukuran bukaan mulut larva bandeng $(214 \mu \mathrm{m})$ dan kakap $(220 \mu \mathrm{m})$, larva kerapu mempunyai ukuran yang lebih kecil $(193 \mu \mathrm{m})$. Selanjutnya dikatakan bahwa pada hari ke-2 sampai hari ke-3 merupakan masa kritis karena pada saat itu larva mengalami pergantian sumber nutrisi yang semula diperoleh dari dalam tubuh beralih ke sumber nutrisi yang berasal dari luar tubuh dan merupakan tahap penyesuaian. Keadaan ini sering menyebabkan tingginya mortalitas pada awal pemeliharaan.

Sintasan tertinggi pada d-5 dicapai oleh perlakuan A (25 ind. $/ l$ ) sebesar $29,40 \%$, diikuti B $(19,46 \%)$ dan terendah C $(10,29 \%)$. Semakin tinggi kepadatan larva dalam bak pemeliharaan sintasan yang dicapai semakin menurun. Terjadinya keadaan ini diduga bahwa dengan semakin tinggi kepadatan larva dalam satu area akan mempersempit ruang gerak juga menyebabkan persaingan dalam mendapatkan pakan yang pada gilirannya akan meningkatkan risiko kematian larva. Akibat lain dengan tingginya kepadatan larva akan menyebabkan rendahnya kualitas lingkungan sebagai akibat banyaknya sisa metabolisme/ekskresi yang dikeluarkan larva dan terurai di dasar bak. Sejalan dengan lamanya pemeliharaan mengakibatkan lingkungan tidak mampu lagi mendukung kehidupan larva. Dibandingkan dengan penelitian Kohno et al., 1990b, Sunyoto et al., 1990 dan Kohno et al., 1994 yang menghasilkan tingkat sintasan larva kerapu sebesar $1-11 \%$ pada d-5, maka dalam penelitian ini nampaknya tingkat sintasan larva dapat diperbaiki. Tetapi pada d-15 terjadi kematian total pada satu ulangan perlakuan A sehingga rata-rata sintasan yang dicapai sebesar 5,65\% dan ternyata lebih kecil dari rata-rata sintasan pada perlakuan B $(6,72 \%)$. Kematian total yang terjadi pada d-15 diduga kondisi larva pada saat itu tidak cukup mampu menyesuaikan diri dengan perubahan jenis pakan yang diberikan. Dengan diberikannya pakan buatan, pergantian air harus sering dilakukan untuk mengantisipasi lingkungan yang tidak mendukung kehidupan ikan. Namun dengan terjadinya goncangan kualitas air akibat pergantian air menyebabkan kondisi ikan yang lemah menjadi semakin lemah dan akhirnya mati. Kematian total juga terjadi pada satu ulangan perlakuan C (75 ind./l), yaitu pada d-28. Ciri khusus kerapu bebek berupa bintik hitam di seluruh permukaan tubuh larva yang nampak muncul pada d-27 sampai d-29 me- rupakan tanda masa kritis yang menentukan sintasannya. Pada keadaan seperti tersebut yakni larva dalam kondisi lingkungan dengan kepadatan yang tinggi, terjadi persaingan dalam memperoleh pakan yang merupakan sumber energi untuk mempertahankan sintasannya. Dibanding. kan dengan penelitian Muchari et al., 1991 yang menghasilkan sintasan sebesar $0,02-4 \%$ pada $d$ 28 , sintasan yang dicapai pada penelitian ini memberikan hasil relatif sama dan terlihat perlakuan B (1,95\%) memberikan hasil yang lebih baik daripada $\mathrm{A}(0,05 \%)$ dan $\mathrm{C}(0,2 \%)$.

Keragaan larva yang dipantau setiap 5 hari dengan menggunakan mikroskop memperlihatkan pertumbuhan panjang tubuh (TL), sirip punggung (DS), sirip dada (PS) dan lebar tubuh (BD) pada masing-masing ulangan perlakuan tidak seragam, namun berdasarkan hasil uji sidik ragam di antara perlakuan tidak berbeda nyata $(P>0,5)$. Perkembangan panjang dan lebar tubuh masing-masing perlakuan yang dipantau setiap 5 hari sampai hari ke-30 (Figure 2), nampak perlakuan B (50 ind./l) memberikan hasil terbaik daripada A dan C.

Sirip punggung dan sirip dada pada d-5 semua perlakuan belum tumbuh, namun organ dalam seperti jantung, lambung dan usus sudah nampak berkembang. Pada d-10 pigmentasi mata sudah sempurna, sirip punggung dan sirip dada mulai berkembang dengan kisaran panjang berturutturut 0,68-0,90 dan 0,72-1,00 mm. Keadaan seperti ini juga ditemui pada larva kerapu sunu, Plectropomus maculatus (Diani et al., 1991) bahwa calon sirip punggung mulai terbentuk pada larva umur 7 hari. Pada d-15 sirip

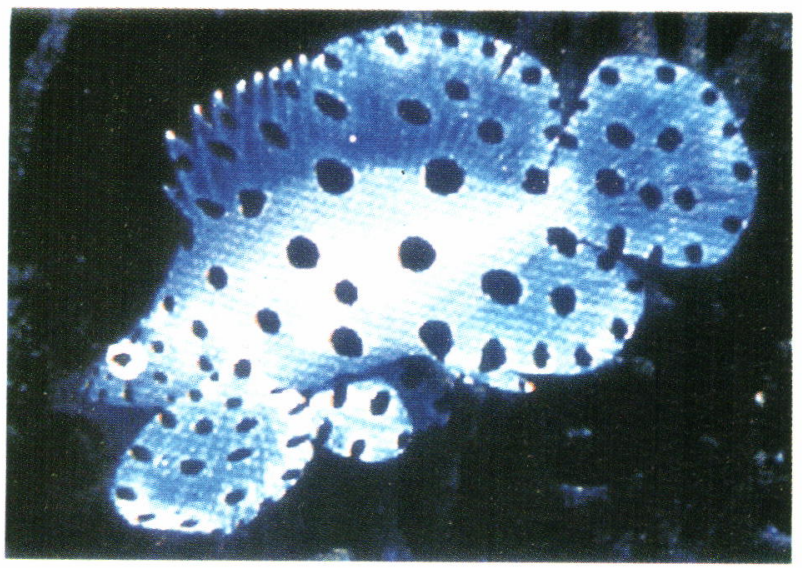

Cromileptes altivelis 
punggung dan sirip dada semakin berkembang dan nampak tumbuh duri-duri halus yang semakin kokoh pada d-20. Perkembangan sirip punggung mencapai lebih dari setengah panjang tubuhnya terjadi pada d-25 diduga berfungsi sebagai alat keseimbangan dalam bergerak mencari makan, terbukti bila terkena arus, larva belum cukup mampu menghindar dengan cepat.

Ciri khusus ikan kerapu bebek berupa bintik hitam di permukaan tubuhnya mulai muncul pada saat larva berumur 28 hari (d-28) yang diawali tumbuh pada bagian sirip anal dan merata pada tubuh bagian belakang setelah larva berumur 30 hari. Nampaknya pertumbuhan bintik hitam pada tubuh larva merupakan masa kritis dan berpengaruh terhadap daya tahan tubuh yang cenderung menurun dan berlanjut dengan kematian larva sehingga terjadi penurun. an sintasan pada d-30. Bercak hitam ini semakin merata ke seluruh tubuh dan semua sirip sejalan dengan bertambahnya umur larva. Ukuran panjang dan lebar tubuh tertinggi pada d-30 dicapai perlakuan B rata-rata $11,65 \mathrm{~mm}$ dan 4,15 $\mathrm{mm}$. Perkembangan larva kerapu bebek ini sesuai dengan perkembangan larva yang diamati Chintahikul, 1986.

Kualitas air selama pemeliharaan 30 hari menunjukkan kisaran yang relatif sama di antara perlakuan (Table 1) dan masih layak untuk pemeliharaan ikan.

Table 1. The average of water quality every 3 days observation during experiment.

\begin{tabular}{|c|c|c|c|c|}
\hline Variables & & $\begin{array}{c}A \\
(25 \text { ind. } /)^{2}\end{array}$ & $\begin{array}{c}B \\
(50 \text { ind } \Omega)\end{array}$ & $\begin{array}{c}C \\
(75 \text { ind } \Omega)\end{array}$ \\
\hline Temperature & $\left({ }^{\circ} C\right)$ & $27.65 \pm 1.909$ & $28.05 \pm 2.333$ & $27.70 \pm 2.263$ \\
\hline$p H$ & & $8.34 \pm 0.445$ & $8.49 \pm 0.318$ & $8.45 \pm 0.346$ \\
\hline Salinity & $(p p t)$ & $34.50 \pm 2.121$ & $34.50 \pm 2.121$ & $34.50 \pm 2.121$ \\
\hline$D O$ & $(p p m)$ & $6.75 \pm 1.485$ & $6.48 \pm 1.937$ & $6.74 \pm 1.958$ \\
\hline $\mathrm{NO}_{2}-\mathrm{N}$ & $(p p m)$ & $0.979 \pm 0.352$ & $1.188 \pm 0.659$ & $1.292 \pm 0.673$ \\
\hline $\mathrm{NH}_{3}-\mathrm{N}$ & $(p p m)$ & $1.200 \pm 0.641$ & $1.239 \pm 0.727$ & $1.109 \pm 0.416$ \\
\hline
\end{tabular}
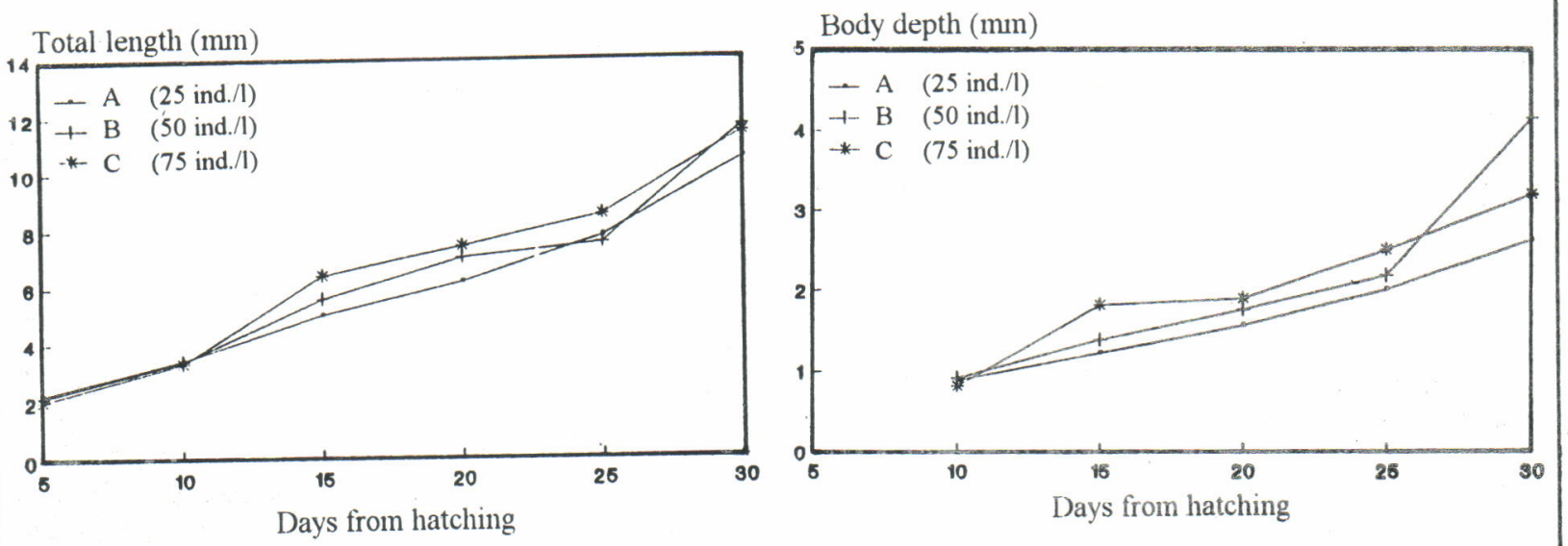

Figure 2. Total length and body depth of grouper larvae, Cromileptes altivelis at different stocking density during 30 days rearing period. 
Suhu, pH, salinitas dan DO (Table 1) menunjukkan kisaran kualitas air yang masih layak untuk pemeliharaan larva ikan laut. Namun kandungan nitrit dan amonia pada semua perlakuan cenderung tinggi. Deodoroff (1957) mengatakan kadar amonia yang layak untuk organisme perairan sebesar $0,2-0,3 \mathrm{ppm}$. Tingginya kandungan amonia pada penelitian ini diduga akibat adanya perombakan nutrien organik protein oleh bakteri, juga akibat adanya ekskresi sisa metabolisme ikan. Penguraian sisa pakan yang mengendap di dasar bak juga dapat mempertinggi kandungan amonia. Di samping itu, pemantauan kualitas air dilakukan pada pagi hari sebelum bak larva disifon, sehingga kandungan amonia cenderung tinggi. Dengan dilakukannya pensifonan yang diikuti pergantian air setiap hari, kualitas air pemeliharaan masih dapat dipertahankan sehingga tidak berpengaruh dan masih layak bagi sintasan ikan.

\section{KESIMPULAN DAN SARAN}

\section{Kesimpulan}

Semakin tinggi kepadatan larva yang ditebar akan semakin tajam penurunan sintasan yang dicapai dalam pemeliharaan selama 5 hari. Sintasan tertinggi pada d-5 sebesar $29,40 \%$, diikuti $19,46 \%$ dan terendah $10,29 \%$ masing-masing dicapai perlakuan A (25 ind. $/ l$ ), B (50 ind. $/ l$ ) dan C (75 ind./l). Sintasan terbaik $(1,95 \%)$ pada $d-30$ dicapai perlakuan $\mathrm{B}$ (50 ind. $/ l$ ) dengan rata-rata panjang total larva sebesar $11,65 \mathrm{~mm}$. Kepadatan larva optimal yang layak untuk pemeliharaan selama 30 hari adalah sebesar 50 ind./l.

\section{Saran}

Teknik pemeliharaan larva secara cermat perlu ditingkatkan terutama waktu pemberian pakan awal dalam jumlah, jenis dan ukuran yang sesuai untuk larva stadia awal, serta teknik pergantian air dengan jumlah dan cara yang tepat sangat menentukan keberhasilan pemeliharaan larva.

\section{UCAPAN TERIMA KASIH}

Terima kasih disampaikan kepada Sdr. Wahyu Handoko mahasiswa Unibraw dan seluruh teknisi kelompok ikan yang telah bersedia membantu dalam pelaksanaan penelitian hingga selesai.

\section{DAFTAR PUSTAKA}

Ahmad T. and P. Sunyoto. 1990. Status and Prospects of marine aquaculture in Indonesia. Indonesia Agriculture and Development Journal. 12(3):46-53.

Ahmad T., S.A. Pranowo dan Yusuf Sutedja. 1991. Polikultur kerapu lumpur, Epinephelus suillus dengan rumput laut, Gracillaria verrucosa dalam karamba jaring apung di tambak. J. Penel. Budidaya Pantai. 7(2):91-101.

Chintahikul T. 1986. Studied on the Breeding and Nursing Technique of the Hump-Backed Rock-Cod (Cromileptes altivelis Curier and Valenciennes). Phuket Brackishwater Fishery Station. Department of Fisheries. Ministry of Agricultural and Cooperations. $29 \mathrm{pp}$.

Deodoroff, P. 1957. Water Quantity Requirements of Fisher and Effects of Toxic Substance in the Physiology of Fishes. Margaret E. Brown. Academic. New York. 403-427 pp.

Diani S., B. Slamet, dan P.T. Imanto. 1991. Studi pendahuluan pemijahan alami perkembangan awal larva ikan kerapu sunu, Plectropomus maculatus.J.Penel.Budidaya Pantai.7(2):10-19.

Kohno H., M. Duray and P. Sunyoto. 1990a. A field guide to groupers of Southeast Asia. Seri Pengembangan Hasil Penelitian Perikanan No. PHP/KAN/ PT 14, Puslitbang Perikanan, Deptan, Jakarta. 26 hal.

Kohno H., S. Diani, P. Sunyoto, B. Slamet and P.T. Imanto. 1990b. Early developmental events associated with changeover of nutrient sources in the grouper, Epinephelus fuscoguttatus larvae. Bull. Pen. Perikanan. Spec. Ed. No. 1:51-64

Kohno H., Ohno, A. and Taki, Y. 1994. Why is grouper larval rearing difficult: A comparison of the biological natures of early larvae of four tropical marine fish species. The Third Asian Fisheries Forum. Asian Fisheries Soc., Manila, Philippines. p 450-453.

Mayunar S. Rejeki dan S. Murtiningsih. 1991. Pemeliharaan larva kerapu macan, $E$. fuscoguttatus dengan frekuensi pemberian ransum rotifera. J. Penel. Budidaya Pantai 7(2):35-41.

Mishina H. and B. Gonzares. 1994. Some Biologi-cal and Ecological Aspects on Cromileptes altivelis around Palawan Island, Philippines. Suisanzoshoku 42(2):345-349.

Muchari A. Supriatna, R. Purba, T. Ahmad dan H. Kohno. 1991. Pemeliharaan larva kerapu macan, Epinephelus fuscoguttatus. Bulletin Penelitian Perikanan. Special Edition No.2:43-52. 
Purba R., dan S. Rejeki. 1992. Studi awal pemeliharaan larva kerapu sunu, Plectropomus maculatus dengan kepadatan berbeda. J. Penel. Budidaya Pantai 8(5):21-26.

Sunyoto, P., A. Basyarie, B. Slamet dan H. Kohno. 1990. Kelulushidupan dan pertumbuhan larva kerapu macan, Epinephelus fuscoguttatus, yang diberi pakan rotifer dan gabungan rotifer dengan telur trochopor tiram. Bull. Pen. Perikanan. Spec. Ed. No. 1:65-69.

Waspada, Muchari, T. Ahmad, Mayunar, S. Diani, dan M. Ali. 1991. Studi pendahuluan tentang pengaruh perbedaan ransum induk terhadap pertumbuhan dan kelangsungan hidup larva ikan kerapu macan, Epinephelus fuscoguttatus. J. Penel. Budidaya Pantai 7(2):26-34. 